\title{
Efikasi Kombinasi Rebamipide dengan Lansoprazole pada Proses Penyembuhan Tukak Lambung Tikus yang Dipapar Indometasin
}

\author{
Efficacy of Lansoprazole-Rebamipide Combination for Healing Process of Gastric Mucosa \\ Indomethacine Exposed in the Rats
}

\author{
Mia Melinda, Harijono Ahmad \\ Laboratorium IImu Penyakit Dalam Rumah Sakit Umum Daerah Dr. Saiful Anwar Malang
}

\begin{abstract}
ABSTRAK
Gastropati akibat penggunaan NSAID masih merupakan permasalahan kesehatan di Indonesia dengan standar terapi lansoprazol yang menekan produksi asam di lambung. Disisi lain pemberian NSAID menginduksi kerusakan mukosa dengan menghambat faktor defensive mukosa, sehingga dapat dikelola dengan obat yang menghambat proses inflamasi yaitu rebamipide. Studi dilakukan untuk mengidentifikasi efektifitas kombinasi lansoprazol dan rebamipid dibanding penggunaan tunggal. Desain experimental post test only group dilakukan pada empat kelompok perlakuan yaitu 1) kelompok kontrol positif dengan induksi indometasin, 2) rebamipid, 3) lansoprazol, dan 4) kombinasi. Pengamatan dilakukan pada jam ke 12, 24, 36 dan 48 jam untuk mengetahui ukuran dan derajat ulkus (kriteria Dixon), jumlah VEGF dan MVD dan dianalisis menggunakan uji One Way ANOVA. Semua terapi dapat memperbaiki ulkus dengan efek tercepat (24 jam) pada terapi lansoprazol saja diikuti terapi kombinasi. Secara histologi pemberian terapi lansoprazol memberikan gambaran normal pada jam ke 48. Ekspresi VEGF dan MVD meningkat pada semua kelompok sejak jam ke 12, dengan jumlah tertinggi pada kelompok terapi lansoprazol. Dapat disimpulkan penambahan rebamipid tidak mempercepat proses kesembuhan dibandingkan terapi tunggal lansoprazol.
\end{abstract}

Kata Kunci: NSAID, lansoprazole, rebamipide

\begin{abstract}
NSAID gastropathy is remains a major problem in Indonesia.Standard therapy for NSAID gastropathy is lansoprazol, to repress acidity of the stomach. NSAIDs induce mucosal damage by disrupting the mucosal defensive factors, the treatment could be used drugs that inhibit gastric mucosal inflammation such as rebamipide. This research aimed to whether the combination of lansoprazole-rebamipide can heal gastric mucosa damaged earlier than rebamipide or lansoprazole alone. The experimental post test group design was performed in 4 groups, group I: Indometasin as positive control, II: Indometasin + Rebamipide, III: Indometasin+Lansoprazole, IV: Indometasin + Rebamipide + Lansoprazole. The observations was performed at the $12^{\text {th }}, 24^{\text {th }}, 36^{\text {th }}$ and $48^{\text {th }}$-hour, to know size and grade of ulcus (Dixson criteria), the amount of VEGF and MVD. All treatment could heal ulcus. The earlier treatment was lansoprazole group ( $24^{\text {th }}$ hour), followed by combination group. Histologically, lansoprazole group got normal in $48^{\text {th }}$ hour $(p=0,008)$. VEGF and MVD expression increased in all group since $12^{\text {th }}$ hour, the highest was lansoprazole group $(p=0,001)$. The addition of rebamipide does not accelerate the healing process compared to single lansoprazole.
\end{abstract}

Keywords: NSAID, lansoprazole, rebamipide

Jurnal Kedokteran Brawijaya, Vol. 26, No. 3, Februari 2011; Korespondensi: Mia Melinda. Laboratorium Ilmu Penyakit Dalam Rumah Sakit Umum Daerah Dr. Saiful Anwar Malang, Jl. Jaksa Agung Suprapto No. 2 Malang Tel. (0341) 362101 Email: mia.melinda@yahoo.com 


\section{PENDAHULUAN}

Penggunaan obat-obat golongan NSAID (non steroid anti inflammation drug) semakin banyak digunakan untuk mengobati pasien yang menderita nyeri kronis baik yang diberikan oleh dokter atau yang dibeli bebas oleh masyarakat (1). Hal ini diikuti dengan makin meningkatnya angka kejadian efek samping dari golongan obat ini khususnya terhadap lambung,yang dikenal dengan gastropati. NSAID dapat menimbulkan kerusakan pada mukosa lambung melalui efek topikal dan sistemik. NSAID lebih berperan dalam menyebabkan kerusakan mukosa atau tukak melalui proses inflamasi dan mengganggu faktor defensif mukosa lambung (1).

Gambaran klinis gastropati ini sangat bervariasi mulai dari tidak menimbulkan keluhan, dispepsia, terjadi ulkus, perdarahan saluran cerna bahkan perforasi (2). Data endoskopi berbasis rumah sakit menunjukkan komplikasi saluran cerna akibat penggunaan NSAID di Makasar 71\%, Jakarta $67,7 \%$, dan Surabaya $61 \%$ (2). Data di ruang endoskopi RSSA menunjukkan prevalensi NSAID gastropati di Malang pada tahun 2008 sebesar 385 dari total 738 pasien yang menjalani endoskopi (sekitar 52\%) terbanyak di antaranya $(56,6 \%)$ adalah gastritis erosive sisanya adalah tukak (2)

Obat yang disetujui oleh FDA untuk pengobatan dan pencegahan tukak lambung akibat NSAID adalah lansoprazol yang bekerja dengan menghambat sekresi asam lambung yang bersifat merusak mukosa lambung (menekan faktor agresif) (4). Obat sitoprotektif yang disetujui oleh FDA untuk pencegahan tukak akibat NSAID adalah misoprostol (analog prostaglandin). Obat ini sangat jarang dipakai karena efek sampingnya yang sangat mengganggu yaitu diare (10-30\%), perdarahan uterus dan kontraksi uterus, sehingga dikontraindikasikan pada wanita usia subur yang mungkin hamil (3-5).

Rebamipide (2-(4-chlorobenzoylamino)-3-[2(1H)quinolinon-4-yl]-propionic acid) telah digunakan untuk pengobatan tukak pada beberapa daerah di Asia. Obat ini mempunyai efek sitoprotektif dengan meningkatkan prostaglandin di mukosa lambung dan sebagai scavenging reactive oxygen species (3). Data klinis dan eksperimental menunjukkan bahwa rebamipide mempercepat perbaikan ulkus lambung, mencegah kekambuhan ulkus dan melindungi mukosa lambung dari kerusakan akut (6). Penelitian Thong et al pada manusia juga mendapatkan bahwa rebamipide $100 \mathrm{mg}$ yang diberikan 3 kali dalam satu hari dapat menyembuhkan NSAID gastropathy yang dinilai dari perbaikan gejala klinis dan skor inflamasi gaster berdasarkan pemeriksaan endoskopi (7) namun diperlukan waktu delapan minggu. Penelitian ini dilakukan untuk mengetahui apakah pemberian kombinasi obat dengan mekanisme kerja berbeda, yaitu rebamipide dengan lansoprazole dapat lebih dini menyembuhkan luka mukosa lambung dibandingkan dengan pemberian rebamipide atau lansoprazole tunggal.

\section{METODE}

Penelitian dilakukan dengan desain randomized control group, post-test only menggunakan 68 tikus wistar umur 2,5-3 bulan, berat badan tikus berkisar 150-250 gram. Penelitian eksperimental ini dilaksanakan di laboratorium fisiologi Fakultas Kedokteran Universitas Brawijaya Malang dan Laboratorium Patologi Anatomi Fakultas
Kedokteran Universitas Gajah Mada Yogyakarta dan telah mendapatkan keterangan kelaikan etik oleh Komisi Etik Penelitian Kesehatan Fakultas Kedokteran Universitas Brawijaya.

Dilakukan aklitimasi selama tujuh hari dan diberikan diet pakan standar (PARS) kemudian dibagi secara random dalam 5 kelompok yaitu 1 kelompok kontrol negatif (4 tikus), kontrol positif dan 3 kelompok perlakuan masingmasing 16 tikus. Pada kontrol positif tiga kelompok perlakuan diberikan indometasin (Sigma USA) $30 \mathrm{mg} / \mathrm{kg}$ BB secara oral sebagai dosis toksis untuk menimbulkan samping gastropati. Kelompok perlakuan 1 diberikan terapi rebamipide $50 \mathrm{mg} / \mathrm{kgBB}$. Rebamipide digunakan bentuk tablet Mucosta ${ }^{\circledR}$ dilarutkan dengan $0,5 \%$ karboksimetilselulosa. Kelompok perlakuan 2 diberikan terapi lansoprazole $25 \mathrm{mg} / \mathrm{kg} / \mathrm{BB}$ bentuk kapsul, sediaan $30 \mathrm{mg}$ yang dilarutkan menggunakan 0,5\% karboksimetilselulosa.

Parameter kesembuhan ulkus yang dinilai meliputi derajat ulkus secara makroskopis dan mirkoskopis, Vascular Endothelial Growth Factor (VEGF) dan Microvascular Density (MVD). Derajat ulkus diukur secara makroskopis dan mikroskopis. Secara makroskopis, luas area ulkus diukur dengan menggunakan metode planimetric yang dinyatakan dalam mm2 (8). Secara mikroskopis dilakukan pemeriksaan histologis lambung sediaan dengan menggunakan mikroskop kamera binokuler. Derajat ulkus diukur berdasarkan kriteria Dixon dengan nilai 0-3 (normal-terberat) (9).

Untuk mengukur VEGF dibuat slide dari jaringan lambung, diberi anti VEGF mouse monoclonal antibody-3 kemudian diberi antibodi monoklonal primer anti mouse. Sediaan diamati di bawah mikroskop dengan pembesaran 100x. Untuk melihat perubahan warna pada inti sel, dan dihitung tiap 100 sel dalam 3 lapang pandang besar yang dinyatakan dalam jumlah (10).

Untuk mengukur MVD slide jaringan lambung diberi antibodi terhadap faktor von Willebrand (DAKO Envision+System), kemudian diberi antibodi monoklonal primer anti mouse. Slide diperiksa di bawah mikroskop NikonEclipse C 600, dengan kamera Nikon digital Net Camera DN 100 dengan pembesaran 100x dan 200x. Bagian yang diwarnai dipilih 5 area dan ditandai daerah yang menunjukkan neovaskularisasi. Penghitungan microvessel dilakukan pada area tepi ulkus dengan pembesaran 400 kali dengan menghitung sel endotel yang tercat coklat. Rata-rata jumlah mikrovaskuler yang tercatat pada 5 area yang terkaya vaskulernya dihitung sebagai MVD (10). Perbedaan kriteria penyembuhan antar kelompok dimasing-masing waktu diuji dengan One Way ANOVA pada tingkat kepercayaan 95\% dilanjutkan uji LSD.

\section{HASIL}

Hasil penelitian menggambarkan bagaimana perubahan indikator penyembuhan tukak lambung yang diinduksi NSAID (indometasin) setelah diberikan terapi rebamipide, lansoprazole dan kombinasinya. Analisis One Way ANOVA menunjukkan bahwa pemberian ketiga jenis terapi memberikan perbaikan indikator penyembuhan tukak dibandingkan kondisi tukak lambung (kontrol positif) hingga kondisi normal meskipun dengan kecepatan yang berbeda. Perbedaan signifikan antar terapi pada satu waktu ditemukan pada jam ke 24 dan 36 sedangkan pada 
Tabel 1. Perbedaan kriteria penyembuhan tukak lambung antar kelompok dan waktu

\begin{tabular}{lllllll}
\hline \multicolumn{7}{c}{ Rerata luas ulkus (mm2) \pm standar deviasi } \\
\hline Jam ke & Normal & Tukak & Rebamipide & Lansoprazole & Kombinasi & $p$ \\
\hline 12 & 0,00 & $18.90 \pm 15.20$ & $9,54 \pm 11,33$ & $12,81 \pm 4,9$ & $3,15 \pm 2,45$ & 0,156 \\
24 & 0,00 & $4,60 \pm 1,58$ & $5,07 \pm 1,09$ & $0,00 \pm 0,00$ & $1,87 \pm 1,87$ & 0,034 \\
36 & 0,00 & $3,69 \pm 7,38$ & $3,53 \pm 0,52$ & $0,00 \pm 0,00$ & $0,00 \pm 0,00$ & 0,032 \\
48 & 0,00 & $0,75 \pm 1,50$ & $1,28 \pm 1,50$ & $0,00 \pm 0,00$ & $0,00 \pm 0,00$ & 0,279 \\
& & Rerata derajat ulkus pada setiap kelompok perlakuan & & \\
12 & 0,00 & $3,00 \pm 0,00$ & $2,00 \pm 0,00$ & $1,50 \pm 0,577$ & $2,00 \pm 0,00$ & 0,005 \\
24 & 0,00 & $3,00 \pm 0,00$ & $1,50 \pm 0,00$ & $1,00 \pm 0,00$ & $1,50 \pm 0,00$ & 0,010 \\
36 & 0,00 & $2,00 \pm 0,00$ & $1,00 \pm 0,00$ & $1,00 \pm 0,00$ & $1,00 \pm 0,00$ & 0,003 \\
48 & 0,00 & $2,00 \pm 0,00$ & $1,00 \pm 0,00$ & $0,00 \pm 0,00$ & $1,00 \pm 0,00$ & 0,008 \\
& & \multicolumn{7}{c}{ Rerata } & VEGF \pm standar deviasi & & \\
12 & 1,30 & $7,32 \pm 0,27$ & $15,16 \pm 1,23$ & $16,99 \pm 0,99$ & $12,50 \pm 0,43$ & 0,00 \\
24 & 1,35 & $12,00 \pm 0,47$ & $20,99 \pm 0,86$ & $21,49 \pm 0,43$ & $19,16 \pm 0,96$ & 0,00 \\
36 & 1,30 & $13,66 \pm 0,99$ & $24,99 \pm 0,69$ & $36,00 \pm 0,00$ & $26,66 \pm 0,61$ & 0,00 \\
48 & 1,30 & $15,82 \pm 0,43$ & $29,92 \pm 0,50$ & $42,92 \pm 0,83$ & $30,67 \pm 0,00$ & 0,00 \\
& & & Rerata MVD \pm standar deviasi & & $13,1 \pm 0,26$ \\
12 & $2,17 \pm 0,19$ & $6,00 \pm 0,75$ & $15,60 \pm 0,65$ & $16,80 \pm 0,65$ & 0,00 \\
24 & $2,08 \pm 0,32$ & $10,0 \pm 0,43$ & $25,10 \pm 0,26$ & $28,30 \pm 0,42$ & $19,90 \pm 0,48$ & 0,00 \\
36 & $2,08 \pm 0,17$ & $15,2 \pm 0,58$ & $27,60 \pm 0,20$ & $34,90 \pm 0,57$ & $26,30 \pm 1,41$ & 0,00 \\
48 & $2,17 \pm 0,19$ & $17,40 \pm 0,23$ & $29,00 \pm 0,33$ & $41,30 \pm 1,09$ & $28,80 \pm 0,73$ & 0,00 \\
\hline
\end{tabular}

Keterangan: $\mathrm{KN}=$ kontrol negatif $; \mathrm{K} 1=$ Kontrol positif, $\mathrm{K} 2=$ Rebamipide, $\mathrm{K} 3=$ lanzoprasole, $\mathrm{K} 4=$ kombinasi Rebamipide dan lansoprazole

jam ke 12 dan 48 tidak ditemukan perbedaan signifikan.

Bila dilihat dari indikator luas ulkus perbaikan hingga kondisi normal pada pemberian lansoprazole saja dicapai pada jam ke 24, terapi kombinasi pada jam ke 36 sedangkan terapi rebamipide tidak memberikan perbaikan bahkan pada jam ke 48. Temuan serupa juga didapatkan pada kriteria derajat ulkus. Pemberian lansoprazole memberikan perbaikan derajat ulkus sejak jam ke 24 dan mencapai kondisi normal pada jam ke 48, sedangkan terapi rebamipide dan kombinasi meskipun menunjukkan perbaikan pada jam ke 36 tetapi tidak dapat mencapai kondisi normal. Pemberian lansoprazole juga memberikan peningkatan VEGF dan MVD yang lebih cepat dan tinggi dibandingkan terapi rebamipide dan kombinasi (Tabel 1),

\section{DISKUSI}

Dari hasil penelitian terlihat bahwa pemberian lansoprazole, rebamipide dan kombinasinya memberikan perbaikan luas ulkus, derajat kedalaman ulkus, peningkatan kadar VEGF dan MVD dibandingkan kondisi gastropati (kontrol positif) dengan waktu yang berbeda. Pemberian lansoprazole memberikan efek penyembuhan luka yang paling baik dan juga paling awal dibandingkan ketiga kelompok perlakuan lainnya. Hal ini berbeda dengan hipotesis awal penelitian bahwa kelompok kombinasi rebamipide-lansoprazole lah yang akan lebih cepat dalam proses penyembuhan luka, oleh karena kedua obat ini dikatakan memiliki efek yang berbeda proses kerjanya. Rebamipide dikatakan lebih memberikan efek sitoprotektif dengan cara meningkatkan sekresi prostaglandin endogen dan juga meningkatkan mukus dan bikarbonat, sedangkan lansoprazole lebih berperan dalam menekan produksi asam lambung sebagai faktor agresif (11,12). Hasil penelitian ini serupa dengan penelitian oleh Suyata dkk, yang mendapatkan bahwa pada NSAID gastropati pemberian omeprazol (proton pump inhibitor) memberikan perbaikan klinis dan gejala lebih cepat dibandingkan pemberian rebamipide. Studi ini dilakukan dalam waktu singkat yaitu 2 minggu lebih pendek daripada penelitian lainnya. Diduga bahwa efek protektif rebamipide lebih menonjol dibandingkan efek penyembuhannya pada lesi mukosa gaster akibat NSAID (13).

Penelitian yang dilakukan oleh Qi et al mendapatkan hasil bahwa pada tikus yang diberi obat (rebamipide, omeprazole dan kombinasi) memperbaiki kualitas penyembuhan ulkus peptikum, melalui peningkatan level PGE(2), penurunan kadar MDA dan IL-8) dibandingkan tikus kontrol. Kelompok tikus dengan terapi kombinasi menunjukkan peningkatan kadar PGE(2) dan penurunan kadar IL-8 dan MDA yang signifikan dibandingkan kelompok monoterapi (14). Higuchi melaporkan angka kesembuhan sebesar $100 \%$ pada kombinasi omeprazole dengan rebamipide dibandingkan omeprazol tunggal sebesar 96\% (15). Penelitian lain menyatakan bahwa kombinasi rebamipide dan PPI lebih superior daripada PPI tunggal untuk mengobati ulkus ukurannya lebih dari 20 $\mathrm{mm}$ dalam waktu 4 minggu setelah Endoscopic submucosal dissection (ESD) (16-18). Penelitian lain mengatakan bahwa kombinasi ini baik untuk mencegah angka kekambuhan, jadi obat diberikan setelah terjadi kesembuhan (19).

Meskipun NSAID dapat mencetuskan ulkus pada pasien yang aklorhidrik, tetapi ternyata pemberian obat $\mathrm{H} 2$ antagonis atau proton pump inhibitor memberikan efek yang menguntungkan untuk mencegah dan mengobati ulkus akibat NSAID. Hal ini disebabkan karena asam berperan dalam terjadinya ulkus dan mengganggu penyembuhan ulkus akibat NSAID melalui beberapa cara. Asam dapat mengganggu proses penyembuhan dengan menghambat agregasi platelet, di mana agregasi platelet tidak akan terjadi pada $\mathrm{pH}<5,4$ (20). Asam juga dapat mengganggu proses restitusi sehingga erosi yang terjadi di wilayah superfisial akan meluas ke daerah mukosa yang lebih dalam. Adanya asam di lambung akan menghambat 
kerja beberapa faktor pertumbuhan (seperti fibroblast growth factor) yang berperan dalam pertahanan dan juga penyembuhan mukosa (21). Pemberian lansoprazole akan membuat $\mathrm{pH}$ lambung naik dalam waktu 1 jam dan tetap mempertahankan $\mathrm{pH}>6$ (22-24). Oleh karena itu pemberian lansoprazole baik dalam upaya menyembuhkan ulkus lambung.

Lansoprazole tunggal dapat memberikan efek penyembuhan yang baik. Disebabkan karena lansoprazole selain memiliki efek menghambat sekresi asam lambung, juga memiliki efek sitoprotektif pada mukosa lambung. Kobayashi telah melakukan penelitian dan menyatakan bahwa ternyata lansoprazole menstimulasi sekresi prostaglandin endogen oleh mukosa lambung $(25,26)$. Peningkatan produksi prostaglandin dilaporkan juga akan meningkatkan ekspresi VEGF yang berperan dalam proses angiogenesis yang mempercepat proses penyembuhan luka. Prostaglandin juga menstimulasi sekresi mukus dan bikarbonat yang akan meningkatkan proses penyembuhan luka $(10,20)$.

Proses penyembuhan luka lambung membutuhkan penutupan epitel yang sempurna dan penggantian jaringan sub mukosa. Dibutuhkan juga peningkatan jaringan konektif. Matrix metallo proteinase (MMP) berperan penting dalam proses remodeling matriks ekstraseluler pada penyembuhan luka, kadarnya memang rendah pada jaringan normal, tapi akan meningkat pada proses remodelling (27). Penelitian yang dilakukan Kobayashi et al, mendapatkan hasil bahwa pada tikus yang diberi lansoprazole, kadar MMP2 nya akan meningkat sehingga proses penyembuhannya juga berlangsung cepat (25).

Pemberian lansoprazole atau proton pump inhibitor akan meningkatkan $\mathrm{pH}$ lambung. Sebagai mekanisme umpan

\section{DAFTAR PUSTAKA}

1. Yamao JI, Kikuchi E, Matsumoto M, et al. Assesing the Efficacy of Famotidine and Rebamipide in the Treatment of Gastric Mucosal Lesions in Patient Receiving Long-Term NSAID Therapy (FORCEFamotidine or Rebamipide in Comparison by Endoscopy). Journal Gastroenterolgy. 2006; 41(12): 1178-1185.

2. Margaretha T, Astarida AGR, Darmawan PNA, Saputri $\mathrm{JH}$, and Yuso IBM. Penatalaksanaan Gastroenteropati OAINS di Indonesia. Konsensus Nasional 2011. Jakarta, 2011.

3. Hoogerwerf WA and Pasricha PJ. Pharmacotherapy of Gastric Acidity, Peptic Ulcers and Gastroesophageal Reflux Disease. In: Brunton LL (Ed). Goodman \& Gilman's The Pharmacological Basis of Therapeutic 11th edition. New York: McGraw Hills; 2006.

4. Tarigan P. Tukak Gaster. Di dalam: Sudoyo AW (Ed). Buku Ajar Ilmu Penyakit Dalam jilid 1, edisi 4. Jakarta: Balai Penerbitan Ilmu Penyakit Dalam FKUI; 2006.

5. Valle JD. Peptic Ulcer Disease and Related Disorder. In: Kasper DL (Ed). Harrison's Principles of Internal Medicine 17th edition. New York: McGraw Hills; 2008; 1746-1762. balik, tubuh akan meningkatkan kadar gastrin $(28,29)$. Peningkatan kadar gastrin dalam plasma sebesar sebelas kali lipat dalam waktu 2 jam setelah pemberian lansoprazole (30). Gastrin merupakan hormon polipetida yang disintesis di sel gastrin dan berperan penting dalam fungsi saluran pencernaan meliputi sekresi asam, motilitas dan proliferasi sel. Penelitian yang dilakukan Komori dkk menunjukkan bahwa gastrin meningkatkan kadar HB-EGF dan COX-2 yang dapat melindungi mukosa gaster dari kerusakan akibat etanol (31). Gastrin juga merupakan faktor pertumbuhan untuk mukosa lambung. Gastrin memiliki efek tropik pada sel mukosa saluran cerna yang meliputi epitel permukaan dan sel ECL (enterochromaffinlike). Gastrin akan menstimulasi sel ECL untuk melepaskan protein Reg yang terlibat dalam proliferasi sel mukosa lambung $(26,32,33)$. Jadi, dalam kondisi ulkus akut, peningkatan gastrin akibat pemberian lansoprazole akan berguna dalam proses penyembuhan ulkus mukosa lambung. Hagiwara meneliti bahwa pada kelompok tikus yang diberi kombinasi rebamipide dengan omeprazole kadar gastrinnya lebih rendah jika dibandingkan dengan kelompok yang diberi omeprazol tunggal. Mereka menyimpulkan bahwa pemberian rebamipide akan berperan dalam mengurangi efek samping akibat pemberian omeprazol jangka panjang (34). Faktor gastrin inilah yang mungkin memberi penjelasan mengapa pada penelitian kami yang diamati dalam waktu singkat, ulkus di kelompok lansoprazole sembuh lebih awal daripada kelompok kombinasi. Dapat disimpulkan bahwa pemberian rebamipide, lansoprazole dan kombinasinya dapat menyembuhkan luka mukosa lambung yang diinduksi indometasin. Kombinasi rebamipide dengan lansoprazole tidak memberikan perbaikan lebih dini ulkus mukosa lambung tikus yang diinduksi indometasin dibandingkan rebamipide atau lansoprazole tunggal.

6. Tanigawa T, Watanabe T, Ohkawa F, et al. Rebamipide, a Mucoprotective Drug, Inhibits Nsaids-Induced Gastric Mucosal Injury: Possible Involvement of the Downregulation of 15-Hydroxyprostaglandin Dehydrogenase. Journal of Clinical Biochemistry and Nutrition. 2011; 48(2): 149-153.

7. Thong-Ngam D, Chayanupatkul M, Klaikeaw N, Rerknimitr R, and Mahachi V. Effect of Rebamipide on Gastric Ulcer Healing Caused by Helicobacter Pylori and/or NSAID or Non NSAID Non Helicobacter Pylori. Journal of the Medical Association of Thailand. 2009; 92(9): 1207-1212.

8. Marshall JK, Thabane M, and James C. Randomized Active and Placebo Controlled Endoscopy Study of a Novel Protected Formulation of Oral Alendronate. Digestive Diseases and Sciences. 2006; 51(5): 864-868.

9. Dixon MF, Genta RM, Yardle JH, and Correa P. Classification and Grading of Gastritis: The Update Sydney System. The American Journal of Surgical Pathology. 1996; 20(10): 1161-1181.

10. Malara B, Josko B, Tyrpien M, Malara P, and Steplewska K. Dynamics of Changes in Vascular Endothelial Growth Factors (VEGF) Expression and Angiogenesis in Stress Induced Gastric Ulceration in Rats. Journal of Physiology and Pharmacology. 2005; 56(2): 259-271. 
11. lijima, Ichikawa $\mathrm{T}$, Okada $\mathrm{S}$, et al. Rebamipide, a Cytoprotective Drug, Increases Gastric Mucus Secretion in Human: Evaluations with Endoscopic Gastrin Test. Digestive Diseases and Sciences. 2009 July; 54(7): 1500-1507.

12. Maity P, Bindu S, Choubey V, et al. Lansoprazole Protects and Heals Gastric Mucosa from Nonsteroidal Anti-inflammatory Drug (NSAID)-Induced Gastropathy by Inhibiting Mitochondrial as Well as Fas-mediated Death Pathways with Concurrent Induction of Mucosal Cell Renewal. The Journal of Biological Chemistry. 2008; 283(21): 14391-14401.

13. Suyata, Bustami E, Bardiman S, and Bakry F. A Comparison of Efficacy between Rebamipide dan Omeprazole in the Treatment of NSAIDs Gastropathy. The Indonesian Journal of Gastroenterology Hepatology and Digestive Endoscopy. 2004; 5(3): 8994.

14. Qi Z, Jie L, Haixia J, and Xiaoying Z. Effect of Rebamipide on Quality of Peptic Ulcer Healing in Rat. Digestive Diseases and Sciences. 2009; 54(9): 1876-1883.

15. Higuchi K, Arakawa T, Nebiki $\mathrm{H}$, et al. Rebamipide Prevents Recurrence of Gastric Ulcer Without Affecting Helicobacter Pylori Status. Digestive Diseases and Sciences. 1998; 43(9): 99S-106S.

16. Kato T, Araki H, Onogi F, et al. Clinical trial: Rebamipide Promotes Gastric Ulcer Healing by Proton Pump Inhibitor after Endoscopic Submucosal Dissection-A Randomized Controlled Study. Journal of Gastroenterology. 2010;45(3): 285-290.

17. Shin WG, Kim SJ, Choi MH, et al. Can Rebamipide and Proton Pump Inhibitor Combination Therapy Promote the Healing of Endoscopic Sub Mucosal Dissesctioninduced Ulcers? A Randomized, Prospective, Multicenter Study. Gastrointestinal Endoscopy. 2012; 75(4): 739-747.

18. Fujiwara S, Morita Y, Toyonaga T, et al. A Randomized Controlled Trial of Rebamipide Plus Rabeprazole for the Healing of Artificial Ulcers after Endoscopic Submucosal Dissection. Journal of Gastroenterology. 2011; 46(5): 595-602.

19. Yoshida N, Kamada K, Tomatsuri N, et al. Management of Recurrence of Symptoms of Gastroesophageal Reflux Disease: Synergistic Effect of Rebamipide with $15 \mathrm{Mg}$ Lansoprazole. Digestive Diseases and Sciences. 2010; 55(12): 3393-3398.

20. Wallace JL. Prostaglandin, NSAIDs, and Gastric Mucosal Protection: Why Doesn't the Stomach Digest Itself? Physiological Reviews. 2008; 88: 1547-1565.

21. Wallace JL. Pathogenesis of NSAID-Induced Gastroduodenal Mucosal Injury. Best Practice \& Research Clinical Gastroenterology. 2001; 15(5): 691703.

22. Metz DC, Devlin JW, Vakily M, Atkinson S, and LloydE. Greater Immediate Gastric Acid Suppression with Lansoprazole $30 \mathrm{Mg}$ Administered As A 2-Minute Intravenous Bolus Injection Versus A 30-Minute Infusion. Pharmacotherapy: The Journal of Human
Pharmacology and Drug Therapy. 2008; 28(3): 301307.

23. Metz DC, Amer F, Hunt B, Vakily M, Kukulka MJ, and Samra N. Lansoprazole Regimens that Sustain Intragastric $\mathrm{pH}>6.0$ : An Evaluation of Intermitten Oral and Continuous Intravenous Infusion Dosages. Allimentary Pharmacology and Therapeutics. 2006: 23(7): 985-995.

24. Bell N, Karol MD, Sachs G, Greski-Rose P, Jennings DE, and Hunt RH. Duration of Effect of Lansoprazole on Gastric $\mathrm{pH}$ and Acid Secretion in Normal Male Volunteers. Allimentary Pharmacology and Therapeutics. 2001; 15(1): 105-113.

25. Kobayashi S, Nakajima N, Ito $\mathrm{Y}$, and Moriyama M. Effects of Lansoprazole on the Expression of VEGF and Cellular Proliferation in a Rat Model of Acetic AcidInduced Gastric Ulcer. Journal of Gastroenterology. 2010; 45(8): 846-858.

26. Tsuji S, Sun WH, Tsuji M, et al. Lansoprazole Induces Mucosal Protection through Gastrin ReceptorDependent Up-Regulation of Cyclooxygenase-2 in Rats. Journal of Pharmacology and Experimental Therapeutics. 2002; 303(3): 1301-1308.

27. Tanigawa T,Watanabe $\mathrm{T}$, et al. Lansoprazole, a Proton Pump Inhibitor, Suppresses Production of Tumor Necrosis Factor-Alpha and Interleukin-1 Beta Induced by Lipopolysaccharide and Helicobacter Pylori Bacterial Components in Human Monocytic Cells Via Inhibition of Activation of Nuclear Factor-kB And Extracellular Signal-Regulated Kinase. Journal of Clinical Biochemistry and Nutrition. 2009; 45(1): 8692.

28. Stephen B. Intisari Biologi. Jakarta: PT. Gramedia Pustaka Utama; 2003.

29. Martini FH and Nath JL. Fundamentals of Anatomy and Physiology. 8th edition. San Fransisco: Pearson Education Inc.; 2009.

30. Lee $H$,Hakanson $R$, Karlsson A, Mattsson $H$, and Sundler F. Lansoprazole and Omeprazole Have Similar Effects on Plasma Gastrin Levels, EnterochromaffinLike Cells, Gastrin Cells and Somatostatin Cells in the Rat Stomach. Digestion. 1992; 51(3): 125-132.

31. Komori M, Tsuji S, Sun WH, et al. Gastrin Enhances Gastric Mucosal Integrity Through Cyclooxygenase-2 Upregulation in Rats. Gastrointestinal and Liver Phsiology. 2002; 283(6): G1368-G1378.

32. Okabe $S$ and Amagase K. An Overview of Acetic Acid Ulcer Models-the History and State of the Art of Peptic Ulcer Research. Biological and Pharmaceutical Bulletin. 2005; 28(8): 1321-1341.

33. Jain RN and Samuelson LC. Differentiation of the Gastric Mucosa. Role of Gastrin in Gastric Epithelial Cell Proliferation and Maturation. Gastrointestinal and Liver Phsiology. 2006; 291(5): G762-G765.

34. Haqiwara T, Mukaisho K, Ling ZK, Sakano T, Sugihara H, and Hattori T. Rebamipide Contributes to Reducing Adverse Effects of Long-Term Administration of Omeprazole in Rats. Digestive Diseases and Sciences. 2007; 52(4): 988-994. 